\title{
THE TOXIC FACTORS IN EXPERIMENTAL TRAUMATIC SHOCK. II. STUDIES ON ELECTROLYTE AND WATER BALANCE IN SHOCK ${ }^{1}$
}

\author{
By A. M. BRUES, W. E. COHN, S. S. KETY, I. T. NATHANSON, A. L. NUTT, \\ D. M. TIBBETTS, P. C. ZAMECNIK, AND J. C. AUB \\ (From the Medical Laboratories of the Collis P. Huntington Memorial Hospital of \\ Harvard University at the Massachusetts General Hospital, Boston, Massachusetts)
}

(Received for publication April 9, 1945)

It is recognized that capillary permeability may be altered locally in burned or traumatized areas, and that the consequent loss of fluid from the blood stream is important in producing shock. It is less certain whether general changes in capillary permeability exist outside of injured areas, except as a very late phenomenon. It is desirable to know also whether changes in permeability of tissue cells occur in shock, locally or generally, along with the reduced capillary blood flow and resulting anoxia. The present study was made in order to determine whether, in various forms of shock, there are important shifts of water or electrolytes between cells and extracellular spaces.

A study was made of the body water distribution in 5 dogs in which shock was produced by hemorrhage and in 3 dogs by hammer trauma to a hind leg (12). It was concluded that there is a passage of water from extracellular spaces into cells following hemorrhage, while in traumatic shock there is an unexplained passage of water out of cells. Two workers (13) studied the water, potassium, and phosphorus content of tissues in 6 control dogs and 4 dogs in which shock occurred following light blows on the thigh, and in a larger series of rats that went into shock following rotation in a drum (5). Tissue analyses made at the verge of death revealed increases in muscle potassium and phosphorus of dogs in shock, whereas in rats the liver lost potassium and phosphorus. The increases found in dogs were considered to result from loss of potassium from traumatized areas. A marked decrease in the potassium content and an increase (double or

1 This is reprint No. 606 of the Cancer Commission of Harvard University.

The work described in this paper was done under a contract, recommended by the Committee on Medical Research, between the Office of Scientific Research and Development and the Massachusetts General Hospital. higher) in the chloride content of traumatized muscles was reported with a slight decrease in plasma chloride, no consistent change in plasma sodium, and a slight rise in plasma potassium, becoming marked just before death (6). In crush injury it has been observed (9) that the necrotic muscle may lose 50 to 90 per cent of its potassium and 65 to 70 per cent of its creatine.

\section{METHODS}

Shock was produced in dogs with the following techniques :

(a) Hemorrhage (6 dogs). This was done by serial bleedings until the blood pressure was below 60 , after which continuous observations were made until death. The initial bleeding was made equal to 2 per cent of the body weight; subsequent smaller bleedings were done at intervals of $1 / 2$ to 1 hour.

(b) Application of a Duncan-Blalock press (6) (5 dogs) to one thigh with a pressure of 500 pounds over a period of 5 hours, following which the press was removed.

(c) Application of a tourniquet as high as possible on one hind leg with sufficient pressure to obliterate femoral artery pulsation. The tourniquet was removed after 5 hours (2 dogs).

(d) The muscle ligation procedure which has been described (7) ( 7 dogs). In these animals the triceps surae muscle groups were rendered ischemic by tying for 5 hours, after which the ties were removed.

All of these procedures were carried out under sodium pentobarbital anesthesia. Animals were originally given intravenously $30 \mathrm{mgm}$. sodium pentobarbital per $\mathrm{kgm}$. with additional doses of 30 to $60 \mathrm{mgm}$. only when restless. In addition, one control dog was maintained under sodium pentobarbital anesthesia and subjected to other procedures common to the experiments over a 10-hour period and was then sacrificed.

Most of these dogs were given intravenous injections of radioactive sodium $\left(\mathrm{Na}^{24}\right)$ or of sodium thiocyanate ( 250 to $500 \mathrm{mgm}$.) or both and serial blood samples taken for determination of extracellular space throughout the experiments; at the same time hematocrits, hemoglobin, and plasma sodium (15), potassium (16), and chloride (17) determinations were made. Thiocyanate determina- 
tions were made by the method of Chesley (18). Total blood removal for these determinations ranged between 100 and $150 \mathrm{ml}$. Early in the experiments, 3 to 4 grams of rectus muscle and liver tissue were removed from most of the dogs by sterile operative techniques, for control tissue analyses. At death, rectus muscle and liver were removed, and in experiments dealing with trauma or ischemia samples of sartorius and gastrocnemius muscles were also taken. Thus in the Duncan-Blalock press group, one sartorius muscle was taken from the crushed area, and a gastrocnemius muscle was removed from the area rendered ischemic below the clamp in addition to the uninjured muscles from the control legs; in the muscle-tying group, samples of an uninjured sartorius and a gastrocnemius muscle which had been rendered ischemic were obtained. These tissues were divided into 3 samples of 1 to 2 grams each, weighed, and kept in petri dishes frozen over $\mathrm{CO}_{2}$ snow. Analyses were made for water, fat, hemoglobin, sodium, potassium, nitrogen, and radiosodium. With certain slight modifications, the handling and analysis of tissues were done according to the procedures described by Lowry and Hastings (16). Tissue sodium determinations were done by the method of Leva (15), and hemoglobin by the procedure described by Cohn (19). Tissue chloride determinations became contaminated by hydrochloric acid fumes in the laboratory hood and were therefore discarded. From the results of blood and tissue analyses, sodium space was determined in the tissues, and cell potassium was calculated in terms of milliequivalents per kilogram of wet cells, as if sodium space represented true extracellular volume. The methods of calculation were similar to those of Hastings and Eichelberger (20) except that cell potassium has been expressed in terms of intracellular volume ${ }^{2}$ instead of intracellular water. In many animals, one or more lobes of the liver were perfused in situ by allowing isotonic sucrose solution to flow through the portal vein at a pressure of 100 to $200 \mathrm{~mm}$. of solution. This was continued until blood was practically removed, and analyses were done on tissues and perfusates.

\section{RESULTS}

Total extracellular space. The results of determinations of thiocyanate and radioactive sodium spaces are summarized in the first table. In all cases, the $\mathrm{Na}^{24}$ and thiocyanate lost by removal of blood were deducted from each succeeding calculation, so that the resulting values indicate extracellular space remaining in the animal.

All of the variations seen are practically within the limits of error of the analytical methods. It will be seen that there is a decrease in thiocyanate space amounting to 2.3 per cent of body weight in hemorrhaged dogs. The individual dogs showed changes ranging between 6.6 per cent loss

\footnotetext{
2 Strictly speaking, non-sodium volume.
}

TABLE I

Extracellular space in shock, by thiocyanate and radioactive sodium

Expressed as percentage of body weight. Mean values for each type of experiment.

\begin{tabular}{|c|c|c|c|c|c|c|c|}
\hline $\begin{array}{l}\text { Hemor- } \\
\text { rhage }\end{array}$ & $\begin{array}{c}\text { Control } \\
\text { deter- } \\
\text { mination }\end{array}$ & \multicolumn{2}{|c|}{$\begin{array}{c}1 \text { hour } \\
\text { after hem- } \\
\text { orrhage }\end{array}$} & \multicolumn{2}{|c|}{$\begin{array}{l}1 \text { hour } \\
\text { before } \\
\text { death }\end{array}$} & $\underset{\text { value }}{\text { Terminal }}$ & $\begin{array}{c}\text { Number } \\
\text { of } \\
\text { dogs }\end{array}$ \\
\hline $\begin{array}{l}\mathrm{Na}^{24} \\
\mathrm{SCN}\end{array}$ & $\begin{array}{l}32.4 \\
33.2\end{array}$ & $\begin{array}{l}32.8 \\
31.2\end{array}$ & & $\begin{array}{l}33 \\
30\end{array}$ & & 2.7 & $\begin{array}{l}4 \\
5\end{array}$ \\
\hline $\begin{array}{c}\text { Duncan- } \\
\text { Blalock } \\
\text { press }\end{array}$ & $\begin{array}{c}\text { Control } \\
\text { deter- } \\
\text { mination }\end{array}$ & $\begin{array}{c}\text { Before } \\
\text { removal } \\
\text { of } \\
\text { clamps } \\
\text { or ties }\end{array}$ & $\begin{array}{l}1 \mathrm{~h} \\
\text { aft } \\
\text { rem }\end{array}$ & $\begin{array}{l}\text { lour } \\
\text { ter } \\
\text { oval }\end{array}$ & $\begin{array}{c}2 \text { hours } \\
\text { after } \\
\text { removal }\end{array}$ & $\begin{array}{l}\text { Ter- } \\
\text { minal } \\
\text { value }\end{array}$ & $\begin{array}{l}\text { Num- } \\
\text { ber of } \\
\text { dogs }\end{array}$ \\
\hline $\begin{array}{l}\mathrm{Na}^{24} \\
\mathrm{SCN}\end{array}$ & $\begin{array}{l}32.1 \\
29.8\end{array}$ & $\begin{array}{l}32.7 \\
31.3\end{array}$ & $\begin{array}{l}32 \\
31\end{array}$ & & $\begin{array}{l}35.0 \\
32.5\end{array}$ & $\begin{array}{l}34.8 \\
32.6\end{array}$ & $\begin{array}{l}1 \\
4\end{array}$ \\
\hline $\begin{array}{l}\text { Tourniquet } \\
\text { SCN }\end{array}$ & 36.0 & 38.0 & 40 & 0.7 & 43.3 & 42.0 & 1 \\
\hline $\begin{array}{c}\text { Muscle } \\
\text { ligation } \\
\mathrm{Na}^{24} \\
\mathrm{SCN}\end{array}$ & $\begin{array}{l}30.1 \\
37.7\end{array}$ & $\begin{array}{l}30.5 \\
37.0\end{array}$ & $\begin{array}{l}31 \\
37\end{array}$ & $\begin{array}{l}.0 \\
.1 .2\end{array}$ & $\begin{array}{l}32.4 \\
36.7\end{array}$ & $\begin{array}{l}33.5 \\
35.4\end{array}$ & $\begin{array}{l}2 \\
4\end{array}$ \\
\hline
\end{tabular}

and 1.8 per cent gain. Since the mean loss is of the same order of magnitude as the amount of plasma removed in bleeding, this shift probably does not represent a shift of water from extracellular space to cells, but serves to indicate that no such shift occurred. There was a mean increase of extracellular space in the Duncan-Blalock press group of plus 2.8 per cent; it appears that this shift is mainly due to diffusion into the extracellular space of the leg after removal of the press, since the substances were injected after applying the press. This will be discussed in the next sections.

In agreement with the interpretation that there is little or no shift of water between cells and the extracellular compartment, it will be seen from Table II that plasma chloride values do not show any considerable change during the course of the experiments. Potassium rises considerably and, as has been shown (6), this rise occurs mainly just before death. The averages suggest a terminal rise in plasma sodium in dogs submitted to hemorrhage, but the individual data show a decrease in 1 , increase in 3 , and no change in 2.

Tissue analyses. Two sets of tissue analyses were obtained for sodium and potassium. Values obtained by the 2 sets of analyses differed slightly, and in the case of each electrolyte 1 set was consistently higher than the other. The values shown 
TABLE II

Mean values for plasma chloride, sodium and potassium in shock

\begin{tabular}{l|c|c|c}
\hline \hline & $\begin{array}{c}\text { Plasma } \\
\text { Cl }\end{array}$ & $\begin{array}{c}\text { Plasma } \\
\text { Na }\end{array}$ & $\begin{array}{c}\text { Plasma } \\
\text { K }\end{array}$ \\
\cline { 2 - 3 } & m.eq./l. & m.eq./l. & m.eq./l. \\
Hemorrhage & & & \\
(6 dogs) & 112 & 139 & 3.61 \\
Before hemorrhage & 113 & 141 & 3.51 \\
1 hour after & 113 & 139 & 3.61 \\
2 hours after & 114 & 140 & 4.10 \\
3 to 4 hours after & 116 & 149 & 5.90 \\
Terminal & & & \\
\hline Duncan-Blalock press & & & \\
(5 dogs) & 110 & 135 & 3.38 \\
Control & 110 & 141 & 3.15 \\
Clamp on 1 hour & 108 & 143 & 4.00 \\
Before removal & 108 & 141 & 4.15 \\
1 hour after removal & 107 & 137 & 6.82 \\
Terminal & & & \\
\hline Muscle ligation & & & \\
(7 dogs) & 114 & 142 & 3.84 \\
Control & 112 & 144 & 4.27 \\
1 hour after tying & 113 & 149 & 4.03 \\
Before release & 113 & 148 & 4.03 \\
1 hour after release & 113 & 144 & 6.41 \\
Terminal & & \\
\hline
\end{tabular}

in Table III are from the set of analyses in which control tissues gave closest agreement with published tissue analyses $(20,21)$. In general, the trends observed were followed in both pairs of analyses and in the case of sodium; the same trends were also seen in radioactive sodium analyses.

As shown in the table, significant changes in tissue composition are seen only in the case of analyses of crushed sartorius muscle in the Duncan-Blalock press group and the tied triceps surae muscle. In these muscles, the sodium space is increased and the potassium content is decreased correspondingly. It is of interest that the muscles which were ischemic because of their position below the Duncan-Blalock press do not show these changes, although muscles made ischemic by the ligation technique are similar to crushed muscles, suggesting that operative isolation and handling of the muscles in the ligation procedure may be partly responsible for the changes, or, more likely, that collateral circulation occurred through bone in experiments using the press.

It appears that the mean sodium space of rectus muscles after hemorrhage is somewhat less than that of muscles removed at biopsy. This can partly be explained by lower blood content determined from hemoglobin analyses (3.5 per cent as against 7.4 per cent): After correcting for this, the significance of the difference is doubtful.

Results of liver perfusion at death showed that under the conditions used, blood was virtually re-

TABLE III

Sodium space of tissues, tissue potassium, and cell potassium concentrations*

\begin{tabular}{|c|c|c|c|c|c|c|c|c|c|c|c|c|}
\hline & \multicolumn{3}{|c|}{$E_{n a}$} & \multicolumn{3}{|c|}{$K_{t}$} & \multicolumn{3}{|c|}{$K_{\bullet}$} & \multicolumn{3}{|c|}{$K / N$} \\
\hline & Mean & $\sigma$ & $n$ & Mean & $\sigma$ & $n$ & Mean & $\sigma$ & $n$ & Mean & $\sigma$ & $n$ \\
\hline $\begin{array}{l}\text { Muscle } \\
\text { Biopsy } \\
\text { Hemorrhage } \\
\text { Duncan-Blalock press }\end{array}$ & $\begin{array}{l}28.9 \\
18.3\end{array}$ & $\begin{array}{l}7.4 \\
6.9\end{array}$ & $\begin{array}{l}9 \\
4\end{array}$ & $\begin{array}{r}81.7 \\
100.6\end{array}$ & $\begin{array}{r}5.8 \\
10.8\end{array}$ & $\begin{array}{r}14 \\
4\end{array}$ & $\begin{array}{l}116.3 \\
124.8\end{array}$ & $\begin{array}{l}10.4 \\
21.3\end{array}$ & $\begin{array}{l}9 \\
4\end{array}$ & 2.58 & 0.19 & $\begin{array}{l}6 \\
0\end{array}$ \\
\hline $\begin{array}{l}\text { Normal } \\
\text { Crushed } \\
\text { Ischemic } \\
\text { Muscle ligation }\end{array}$ & $\begin{array}{l}29.7 \\
59.5 \\
27.6\end{array}$ & $\begin{array}{r}6.6 \\
10.1 \\
1.6\end{array}$ & $\begin{array}{r}12 \\
4 \\
4\end{array}$ & $\begin{array}{l}82.0 \\
38.8 \\
80.5\end{array}$ & $\begin{array}{l}14.0 \\
12.7 \\
20.1\end{array}$ & $\begin{array}{r}13 \\
4 \\
4\end{array}$ & $\begin{array}{r}115.4 \\
89.7 \\
109.6\end{array}$ & $\begin{array}{l}20.6 \\
11.2 \\
25.7\end{array}$ & $\begin{array}{r}12 \\
4 \\
4\end{array}$ & $\begin{array}{l}2.51 \\
1.51 \\
2.56\end{array}$ & $\begin{array}{l}0.29 \\
0.47 \\
0.26\end{array}$ & $\begin{array}{r}13 \\
4 \\
4\end{array}$ \\
\hline $\begin{array}{l}\text { Normal } \\
\text { Ischemic } \\
\text { Liver }\end{array}$ & $\begin{array}{l}32.6 \\
60.8\end{array}$ & 3.0 & $\begin{array}{l}4 \\
2\end{array}$ & $\begin{array}{l}85.1 \\
52.0\end{array}$ & 5.5 & $\begin{array}{l}4 \\
2\end{array}$ & $\begin{array}{l}123.0 \\
121.0\end{array}$ & 5.8 & $\begin{array}{l}4 \\
2\end{array}$ & $\begin{array}{l}2.77 \\
1.85\end{array}$ & 0.19 & $\begin{array}{l}4 \\
2\end{array}$ \\
\hline $\begin{array}{l}\text { Biopsy } \\
\text { Hemorrhage } \\
\text { Duncan-Blalock press } \\
\text { Muscle ligation }\end{array}$ & $\begin{array}{l}34.4 \\
26.7 \\
36.4 \\
33.7\end{array}$ & $\begin{array}{l}5.9 \\
2.9\end{array}$ & $\begin{array}{r}10 \\
2 \\
5 \\
2\end{array}$ & $\begin{array}{l}85.9 \\
86.0 \\
79.0 \\
73.2\end{array}$ & $\begin{array}{l}13.1 \\
12.7\end{array}$ & $\begin{array}{r}12 \\
2 \\
4 \\
2\end{array}$ & $\begin{array}{l}117.9 \\
116.5 \\
126.0 \\
108\end{array}$ & $\begin{array}{l}13.9 \\
20.0\end{array}$ & $\begin{array}{l}9 \\
2 \\
4 \\
2\end{array}$ & $\begin{array}{l}2.40 \\
2.26 \\
2.19\end{array}$ & $\begin{array}{l}0.28 \\
0.23\end{array}$ & $\begin{array}{l}8 \\
0 \\
4 \\
2\end{array}$ \\
\hline
\end{tabular}

$\sigma=$ standard deviation

$n=$ number of tissues analyzed.

$E_{n a}=$ sodium space in ml. per 100 grams of tissue.

$K_{t}=$ tissue potassium, m. eq. per $\mathrm{kgm}$. wet tissue.

$K_{\mathrm{c}}=$ intracellular concentration of potassium, m. eq. per kgm. wet cells.

$K / N=$ ratio of potassium (m. eq.) per nitrogen (grams) in tissue.

* Calculations are based on fat-free tissue weights. 
moved from the organs after perfusion with about 4 volumes of isotonic sucrose solution. At this time, extracellular ions (sodium, thiocyanate, chloride) and also considerable amounts of potassium were being removed in decreasing amounts in the perfusion fluids. Extracellular ions and potassium also perfused readily from the liver of the control dog. Liver perfusions by our technique, therefore, do not give an accurate indication of extracellular space, since extravascular and even intracellular components are removed while blood cells are still being washed out.

\section{DISCUSSION}

The data presented above give no indication that there is any consistent shift of water or electrolytes into or out of cells in shock, barring what may occur locally in traumatized regions. This is made clear by the estimations of thiocyanate and radioactive sodium space in which any apparent slight increase in extracellular volume can probably be accounted for by local shifts in the traumatized regions; it is noteworthy that such shifts, when they occur, take place mainly within 2 hours after removal of clamps and ties at the time when local edema is manifest, rather than terminally when shock is greatest. Though the tissue analyses reported leave much to be hoped for as regards consistency, it appears clear that there is a marked loss of potassium and gain in sodium by the clamped and the tied muscles, while there is no change in the sodium and potassium of liver or other muscles within the rather wide limits of variation encountered. Any such shifts in extratraumatic areas could only be demonstrated by a more refined technique. Even if they were found, they might be of doubtful application to human shock, since dogs apparently differ from rats in their handling of liver potassium in shock (13). It is of interest that certain workers have been unable to demonstrate increased capillary filtration, except in regions adjacent to trauma (22).
Areas of traumatization, particularly with the Duncan-Blalock press, show considerable edema; in fact, there is reason to believe that local loss of plasma is a most important factor in production of shock by such means. It is, therefore, worth while to consider whether the shift of tissue water to the extracellular compartment observed in these muscles may be wholly due to infiltration of the tissue with edema fluid. The calculations of intracellular potassium concentration in these tissues (Table III) and in $\mathrm{K}: \mathrm{N}$ ratio show a decrease in cell potassium which is probably beyond the limits of experimental variation, and thus suggest that there is a loss of cell potassium, in addition to edema, amounting in the case of muscle injured by the Duncan-Blalock clamp to about 25 to 40 per cent. In muscle tying, the figures suggest that the loss is smaller. Our results confirm the conclusions of others (6) that the electrolyte changes in shock and in adrenal insufficiency differ fundamentally, although the plasma potassium is elevated in both conditions $(6,23)$.

\section{SUM MARY}

Extracellular space measurements and tissue and blood electrolyte determinations were made on dogs in which shock was produced by hemorrhage and by 3 procedures producing trauma or ischemia.

No evidence was found of significant changes in the extracellular space of the whole body with these procedures except that which occurred locally in traumatized areas.

Plasma sodium and chloride did not show any significant changes; increase in plasma potassium terminally, as reported by others, was confirmed.

Tissue analyses showed marked loss of potassium and gains of sodium by muscles which had been directly traumatized or tied to produce ischemia. This change was probably due in part to local intra- or extra-cellular edema and in part to net loss of potassium from injured cells.

Bibliography follows Paper VI of this series. 